\title{
Marine metagenomics: strategies for the discovery of novel enzymes with biotechnological applications from marine environments Jonathan Kennedy ${ }^{1}$, Julian R Marchesi ${ }^{3}$ and Alan DW Dobson*1,2
}

Address: ${ }^{1}$ Environmental Research Institute, University College Cork, National University of Ireland, Lee Road, Cork, Ireland, ${ }^{2}$ Department of Microbiology, University College Cork, National University of Ireland, Western Road Cork, Ireland and ${ }^{3}$ School of Biosciences, Cardiff University, Cardiff, UK

Email: Jonathan Kennedy - jonathan.kennedy@ucc.ie; Julian R Marchesi - marchesijr@cardiff.ac.uk; Alan DW Dobson* - a.dobson@ucc.ie

* Corresponding author

Published: 2I August 2008

Microbial Cell Factories 2008, 7:27 doi:10.1 186/1475-2859-7-27
Received: 23 July 2008

Accepted: 21 August 2008

This article is available from: http://www.microbialcellfactories.com/content/7///27

(c) 2008 Kennedy et al; licensee BioMed Central Ltd.

This is an Open Access article distributed under the terms of the Creative Commons Attribution License (http://creativecommons.org/licenses/by/2.0), which permits unrestricted use, distribution, and reproduction in any medium, provided the original work is properly cited.

\begin{abstract}
Metagenomic based strategies have previously been successfully employed as powerful tools to isolate and identify enzymes with novel biocatalytic activities from the unculturable component of microbial communities from various terrestrial environmental niches. Both sequence based and function based screening approaches have been employed to identify genes encoding novel biocatalytic activities and metabolic pathways from metagenomic libraries. While much of the focus to date has centred on terrestrial based microbial ecosystems, it is clear that the marine environment has enormous microbial biodiversity that remains largely unstudied. Marine microbes are both extremely abundant and diverse; the environments they occupy likewise consist of very diverse niches. As culture-dependent methods have thus far resulted in the isolation of only a tiny percentage of the marine microbiota the application of metagenomic strategies holds great potential to study and exploit the enormous microbial biodiversity which is present within these marine environments.
\end{abstract}

\section{Introduction}

It has been estimated that pelagic bacteria are extremely abundant, achieving densities of up to $10^{6}$ per ml of seawater, and account for most oceanic biomass and metabolism [1]; while numbers of bacteria which are thought to colonize marine snow can reach levels of up to $10^{9}$ per ml [2]. Marine environments, including the subsurface are believed to contain a total of approximately $3.67 \times 10^{30}$ microorganisms [3] and with approximately $71 \%$ of the earth's surface of 361 million square kilometers covered by the ocean, this environment represents an enormous pool of potential microbial biodiversity and exploitable biotechnology or "blue biotechnology". This untapped potential has resulted in the recent acceleration in interest in the study of marine microorganisms, with the aim of not only providing us with more information on the key role they play in marine food webs and biogeochemical cycling in marine ecosystems, but also in exploiting their ability to produce novel enzymes and metabolites/compounds with potential biotechnological applications. As with terrestrial environments, where more than $99 \%$ of bacteria cannot be cultured by conventional means, the same is true for marine environments where the vast majority of these marine microbes have to date not yet been identified, classified or indeed cultured. According to Amann and colleagues as few as $0.001-0.1 \%$ of 
microbes in seawater are currently cultivable [4]. In this respect the recent advances in culture independent techniques to assess microbial diversity and ecology, such as phylogenetic studies based on small ribosomal RNA (rRNA) analysis and metagenomics, which were initially developed for terrestrial based research are now increasingly being employed in marine environments and are proving extremely useful $[5,6]$. A clear example of this was the large scale metagenome sequencing project which was recently undertaken on oligotrophic seawater samples from the Sargasso Sea [7] and the Global Ocean Sampling (GOS) expedition [8].

In this review, we highlight the exciting potential that metagenomic based approaches offer us in gaining access to protein-coding genes with biotechnological potential from uncultivable marine microorganisms; thereby allowing us to exploit, to a much greater extent than heretofore, the potential of this vast, and as yet untapped, marine microbial biodiversity resource.

\section{Metagenomics}

Against the background whereby it is widely believed that more than $99 \%$ of bacteria in any given environment cannot be cultured when conventional approaches are employed, metagenomic based approaches have emerged as an attractive option to allow an assessment of the microbial genomes present within these environments [9]. Metagenomics involves the direct cloning of environmental DNA into large clone libraries to facilitate the analysis of the genes and the sequences within these libraries (Figure 1) [10,11]. Metagenomics was initially

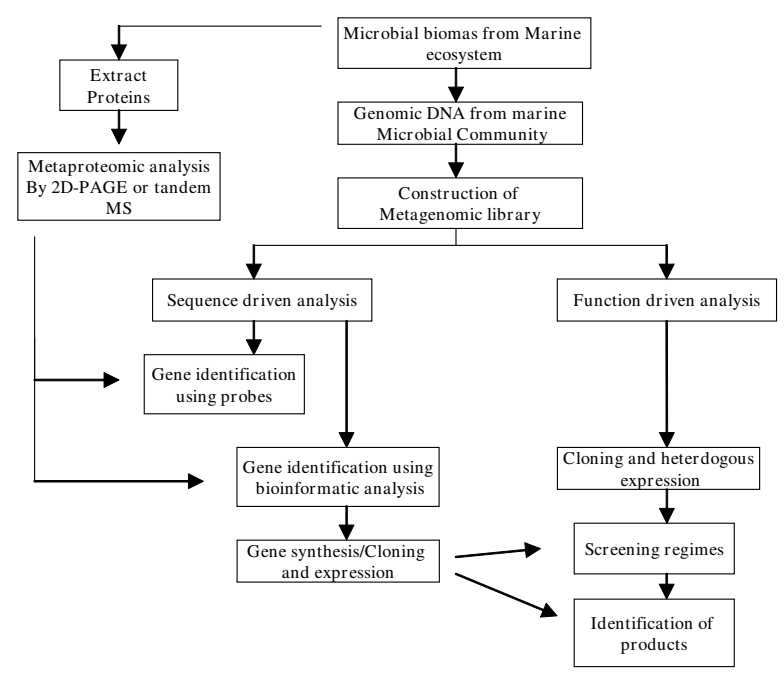

Figure I

Omic based approaches to identify novel biocatalysts from marine ecosystems. employed to study non-culturable microbiota and focused primarily on providing a better understanding of global microbial ecology in different environmental niches. With the advent of efficient cloning vectors such as bacterial artificial chromosomes (BACs) and cosmids, together with improved DNA isolation techniques and advanced screening methodologies using robotic instrumentation; it is now possible to express large fragments of DNA and subsequently screen large clone libraries for functional activities [12]. Such approaches have been particularly successful in terrestrial environments, where genes involved in antibiotic production, antibiotic resistance and degradative enzymes have been identified among others $[10,13,14]$. These approaches coupled with additional innovative screening approaches such as Substrate-Induced Gene Expression screening (SIGEX) have facilitated the cloning of catabolic operons potentially involved in benzoate and catechol degradation among others [15]. These functional based screening approaches have also been supplemented with homology-based screens, primarily involving polymerase chain reaction (PCR)-based approaches targeting novel genes with sequences similar to known genes. This has resulted in the cloning of genes such as polyketide synthases [16], alkane hydroxylases [17], cyclomaltodextrinases [18], xylanases [19] and beta-xylanases [20]. Recently novel methods such as pre-amplification inverse-PCR (PAI-PCR) [21] and metagenomic DNA shuffling [22] have been employed to isolate new biocatalysts. PAI-PCR which has been employed to isolate glycosyl hydrolase genes from horse and termite guts, offers the potential to clone genes for which the copy number of target DNA sequences is low, while the shuffling approach, which has been used to construct novel biocatalysts, simulates and accelerates the evolutionary process using molecular biological tools. Homology-based screening approaches are by definition quite limited, given that homologs of existing genes are being targeted and this often results in no novel gene families being detected. The large scale Global Ocean Sampling Project has revealed that despite the large increase in DNA sequence data we have yet to approach saturation for the discovery of new protein folds, implying that there is a large resource of truly novel proteins and enzymes in uncultured marine microbes [8]. It is thus widely believed that functional-based screening holds far more potential for identifying entirely new enzymes with novel biocatalytic activities [23].

\section{Marine microbes as good sources of novel biocatalysts}

All marine ecosystems are inhabited by microbes, which are both taxonomically diverse and metabolically complex. Marine microbes are both the primary producers of biomass in the oceans, harvesting light and fixing carbon, and the primary recyclers of nutrients. Microbial processes are essential for all the major cycles necessary for the 
maintenance of ocean life. Marine microbes are also known to be involved in the global cycling of bio-elements such as nitrogen, carbon, oxygen, phosphorous, iron, sulphur and trace elements. The precise contribution of marine microbes to these biogeochemical cycles is unknown. However, because of the versatility of their biochemical capabilities and the vast microbial biomass present in marine ecosystems, they are believed to be the main components responsible for the maintenance of these cycles, which help sustain all living things in these ecosystems. [24].

The marine environment is extremely diverse and marine microbes are exposed to extremes in pressure, temperature, salinity and nutrient availability. These distinct marine environmental niches are likely to possess highly diverse bacterial communities, possessing potentially unique biochemistry. Enzymes isolated from microbes from such environments are likely to have a range of quite diverse biochemical and physiological characteristics that have allowed the microbial communities to adapt and ultimately thrive in these conditions. For example bacteria which colonize marine snow are known to produce extracellular enzymes, whose function is to degrade proteins and polysaccharides within the snow [2]. Thus the potential exists to exploit the enzymes produced by these marine microbes which are likely to possess unique biocatalytic activities capable of functioning under extreme conditions.

Microbes are also known to form symbiotic relationships with various marine invertebrates within diverse marine ecosystems; including species of sponges, corals, squids, sea squirts and tunicates among others. The symbioses between the marine invertebrates and the microbes are thought to offer each partner a number of advantages. For example, in the case of sponges symbiotic bacteria are believed to provide a source of nutrients for the sponge host, process sponge metabolic waste and produce secondary metabolites which play a role in the overall defence mechanisms of the sponge [25]. These sponges are rich sources of biologically active and pharmacologically valuable natural products, with the potential for therapeutic use, and the bacterial symbionts of these sponges are widely believed to be the producers of many of these products $[26,27]$. Marine sponges are also known to contain large amounts of halogenated organic compounds such as fatty acids and alkaloids and are thus a potential useful source of both halogenases and dehalogenases a group of biotechnologically important enzymes which can be used in the production of pharmaceuticals, herbicides and pesticides [28-31].

The potential for the discovery of novel enzymes from marine microbes is illustrated by the fact that quite a diverse range of enzymatic activities have to date been identified from cultured marine microbes (Table 1), with the need for novel biocatalysts giving rise to many new enzymes being isolated from the marine environment. These include bacteria isolated from Antarctic seawater and marine sediments among others. Novel enzymes which have recently been identified from marine environments include a non-specific nuclease isolated from a bacteriophage which predates on the marine thermophile Geobacillus sp. 6K51. This enzyme has been shown to have no known homology to any previously isolated enzymes and a temperature optimum of $60^{\circ} \mathrm{C}$ [32]. At the other end of the temperature scale are the cold-adapted enzymes such as the lipase isolated from the $\gamma$-proteobacterium, Pseudoalteromonas haloplanktis TAC125. This lipase is the first member of a new family of lipases, which share homology to the $\alpha / \beta$ hydrolases superfamily [33]. Other recently reported enzymes include phospolipases [34], extracelluar amylotic enzymes [35], agarases [36] and endochitinases [37].

Even environments such as the deep sea floor, where to date only limited numbers of cultivable bacteria have been isolated, mainly obligate sulphate reducing anaerobes and methanogens together with facultative anaerobic heterotrophs such as Halomonas and Psychrobacter, now appear to be reservoirs for microbes with enzymatic activities with potential biotechnological applications. For example a number of cultivable aerobic microbes have recently been isolated from the deep subseafloor sediments from off-shore the Shimokita peninsula in Japan at a water depth of $1,180 \mathrm{~m}$. These microbes produced a variety of different enzymatic activities including protease, amylase, lipase, chitinase, deoxyribonuclease and phosphatase activities [38].

However, these novel enzymes have all been isolated from the cultivable fraction of microbes from the diverse range of marine environments which were studied. As we know this cultivable fraction represents only a small proportion of the total bacteria present in these environments. Hence, if the entire potential of these environments is to be explored and ultimately exploited with respect to the presence of novel biocatalysts; then there is a clear need to employ metagenomic or other culture-independent approaches together with robust heterologous expression systems to facilitate such an approach.

\section{Heterologous expression systems for functional expression of metagenomic libraries from marine environments}

The heterologous expression of novel genes or indeed gene clusters within suitable hosts will be required if new biocatalysts are to be identified from unculturable marine sources. However, significant challenges remain in using functional metagenomic based approaches to identify 
Table I: Enzymes from marine microbes

\begin{tabular}{|c|c|c|c|}
\hline Enzyme & Producing Organism & Habitat & Ref \\
\hline Alanine dehydrogenase & Psychrophilic bacterium strain PA-43 & Sea Urchin & [62] \\
\hline Alcohol dehydrogenase & Flavobacterium frigidimaris KUC-I & Antarctic seawater & [63] \\
\hline Aminopeptidase & Colwellia psychrorythraea strain 34H & Marine sediment & [64] \\
\hline$\alpha$-amylase & Nocardiopsis sp. & Deep sea sediment & [65] \\
\hline$\beta$-Galactosidase & Arthrobacter sp. SB & Antarctic sea water & [66] \\
\hline$\beta$-Galactosidase & Guehomyces pullulans & Antarctic sea water & [67] \\
\hline Catalase & Vibrio salmonicida & Fish microbiota & [68] \\
\hline Cellulase & Pseudoaltermonas haloplanktis & Antartic sea water & [69] \\
\hline Cellulase & Pseudoaltermonas sp. DY3 & Deep-sea sediment & [70] \\
\hline Chitinase & Arthrobacter sp. TAD20 & Antarctic ice & [7I] \\
\hline Chitinase & Rhodothermus marinus & Marine hot springs & [72] \\
\hline Esterase & Vibrio sp. & Sea Hare eggs & [73] \\
\hline Epoxide hydrolases & Erythrobacter litoralis HTCC2594 & Seawater & [74] \\
\hline Feruloyl esterase & Pseudoaltermonas haloplanktis & Antartic sea water & [75] \\
\hline$\beta$-D-glucosidase & Shewanella sp. G5 & Munida subrrugosa (intestine) & [76] \\
\hline Homoserine transsuccinylase & Thermotoga maritima & Marine sediment & [77] \\
\hline Isocitrate dehydrogenase & Colwellia psychrerythraea & Arctic marine sediment & [78] \\
\hline Isocitrate lyase & Colwellia psychrerythraea & Arctic marine sediment & [79] \\
\hline Lipase & Pseudoaltermonas haloplanktis TACI 25 & Antartic sea water & [33] \\
\hline Malate dehydrogenase & Flavobacterium frigidimar KUC-I & Antartic sea water & [80] \\
\hline Quinol oxidase & Shewanella sp. strain DB-I72F & Deep-sea sediment & [8I] \\
\hline Pectate lyase & Pseudoalteromonas haloplanktis strain ANT/505 & Antarctic sea ice & [82] \\
\hline Proteases & Pseudoalteromonas, Shewanella, Colwellia, Planococcus species & Sub-Antarctic sediment & [83] \\
\hline Protease (alkaline) & Pseudomonas strain DY-A & Deep-sea sediment & [84] \\
\hline Proteases (serine) & Marine bacterium & Antartic sea water & [54] \\
\hline Proteases (serine) & Aeropyrum pernix $\mathrm{KI}$ & Coastal solfataric vent & [85] \\
\hline Subtilisin & Bacillus TA 4I & Antartic sea water & [86] \\
\hline Trehalase & Rhodothermus marinus & Marine hot springs & [87] \\
\hline Uracil-DNA Glycosylase & Marine bacterium strain BMTU3346 & Marine sample & [88] \\
\hline Xylanase & Pseudoaltermonas haloplanktis & Antartic sea water & [89] \\
\hline
\end{tabular}

these enzymes; particularly when extreme environments, such as those present in many marine ecosystems, are being targeted. One of the main problems is that of low biomass yields, which coupled with low cell numbers from these marine environments, can lead to difficulties in obtaining high yields of DNA for subsequent cloning. Thus new methods are required to allow metagenomic library construction from environments with only low bacterial cell-densities. One potential method of overcoming this problem is the use of multiple displacement amplification, which has been successfully employed to assess the microbial diversity of scleractinian coral where environmental considerations require minimal sample sizes [39]. In addition, for functional screening to be successful it requires gene expression and proper folding of the resulting protein in a suitable heterologous host. While it has been predicted that $E$. coli expression systems can be employed to successfully express up to $40 \%$ of genes from 32 complete genome sequences of various prokaryotic organisms, this is not always easily achievable [40]. For example insolubility of the target protein remains a major limitation in E. coli expression systems, while in some structural genomics projects, up to half of the targets tested failed to fold properly and accumulated as insoluble protein or inclusion bodies [41]. With this in mind a number of alternative bacterial host and expression systems are currently being examined. These include Streptomyces lividans, Pseudomonas putida and Rhizobium leguminosarum $[42,43]$, which should facilitate the construction of metagenomic libraries with different expression capabilities thereby overcoming some of the difficulties being encountered with the E. coli system. In addition the possibility exists that functional expression of metagenomic DNA from psychrophilic marine microorganisms in heterologous hosts such as E. coli may be sub-optimal when the host is cultured at a higher temperature. The expression of proteins from these psychrophilic microorganisms at higher temperatures may lead to the mis-folding of these proteins and the subsequent formation of inclusion bodies, resulting in loss of function. While this may not always be the case [44], in general psychrophilic microorganisms produce enzymes which have become cold-adapted, but which tend to have a low thermal stability. These problems may potentially be overcome through the use of chaperone-based E. coli strains bearing the chaperonin 60 gene (cpn60) and the cochaperonin 10 gene (cpn10) from the psychrophilic bacterium Oleispira antartica $\mathrm{RB}^{\mathrm{T}}$ [45]. The use of these strains for 
metagenomic library construction could facilitate the functional screening of these libraries at temperatures down to $10^{\circ} \mathrm{C}$, where increased levels of expression may in fact be observed [46].

\section{Successes in the marine environment}

Researchers have also begun to employ metagenomic based approaches in an effort to isolate novel compounds from marine environments. Much of the emphasis to date has focused on the identification of gene clusters encoding novel biosynthesis pathways for compounds with potential bio-pharmaceutical applications, from bacterial populations associated with marine invertebrates [25]. The metagenomic approaches being employed are similar to those that have previously been successfully employed in soil, which have resulted in the identification of among others; a biosynthesis gene cluster for the antibiotic violacein [47]; novel $N$-acyltyrosine antibiotics [48]; the novel antibiotic turbomycins [49]; antibiotic compounds related to indirubin [50]; and a family of novel natural products, the terragenines [51]. Successes in the marine environment include identification of the biosynthetic machinery for the cytotoxic peptide patellamide from the cyanobacterial symbiont, Prochloron, of a marine didemnid ascidian. Two groups independently identified the biosynthesis genes for patellamide using a DNA sequencing approach and through a functional metagenomics approach. Patellamide biosynthesis was found to proceed though modification of a ribosomally encoded peptide and not via a non-ribosomal peptide synthetases as had been previously assumed [52,53].

With respect to biocatalysts, a number of novel hydrolytic enzymes have recently been cloned from Antarctic sea water bacterial metagenomic DNA [54], while a novel low-temperature-active lipase has also recently been isolated from a metagenomic library of Baltic Sea marine sediment bacteria. This low-temperature-active lipase gene which displayed 54\% amino acid similarity to a Pseudomonas putida esterase was successfully heterologously expressed in E. coli and subsequently biochemically characterised [55]. This highlights the value of employing metagenomics in marine environments to, in this case, identify novel lipases. Lipases have important applications not only in the detergent industry but also in paper processing, as food additives [56] and in biofuel production through catalysing the conversion of vegetable oil to methylalcohol ester [57]. They also have applications in synthetic organic chemistry, due primarily to their enantio-/stereoselectivity coupled with their ability to retain activity in organic solvents. Thus similar metagenomics approaches in other marine environments may prove fruitful in identifying other novel lipase genes, with biotechnological applications in these areas.
Another example where metagenomics has been successfully employed to identify novel enzymes from a marine environment is the recent report of the cloning of two alkane hydroxylase genes from a metagenomic library from deep-sea sediment in the Pacific. While this is the first report of the genetic characterisation of an alkane hydroxylase from a deep-sea environment, it is also interesting to note that these two alkane hydroxylase genes were functionally expressed in a Pseudomonas fluorescens strain [17]. Identification of these novel proteins may help to increase the range of alkane hydroxylase biocatalytic applications, and again highlights the utility of metagenomics in identifying potential novel biocatalysts.

\section{Challenges and future directions}

There are several key areas which need to be addressed in order for this exciting area to realise its full potential. The high microbial diversity of these marine environments means that large numbers of clones need to be screened in order to access the full biodiversity of the microbial community and to obtain significant numbers of "hits" which can then be taken forward for further analysis. This requirement means that high throughput screens need to be established to identify positive clones in metagenomic libraries. The development of cell-based ultra-high throughput screens would enable more rapid screening of large metagenomic libraries. Flow cytometry based approaches such as the SIGEX approach are leading the way in this area, since millions of clones can be screened in a short time and sorted for further analysis.

While standard metagenomic approaches allow access to the full biodiversity of microbial populations, the nature of the metagenomic approach means that to access low abundance $(<1 \%)$ microbes, extremely large libraries are required. These large libraries contain significant redundancy with respect to the high abundance microbes present within the population. A combination of cell sorting technology (FACS and microfluidics) and whole genome amplification approaches has the potential to significantly improve the ability to access the genetic resources of low-abundance microbes within any given population [58-60]. These new approaches to access low abundance microbial diversity could be used to make targeted 'metagenomic' libraries of low abundance microbes and increase our ability to access this diversity.

The functional metagenomic approach, typically used for biocatalyst screening, requires that the desired activity be expressed in a surrogate host, typically Escherichia coli. While E. coli has proven to be a flexible and useful host for heterologous expression there are a significant proportion of proteins that cannot be expression functionally in this host. In addition, many functional assays rely on the 
expression of entire metabolic pathways, requiring that promoters be recognised in the heterologous host for the co-ordinated expression of entire sets of genes. The range of surrogate hosts for heterologous expression and their associated vectors needs to be greatly expanded if we are to succeed in expressing DNA from the many diverse phyla that exist in the marine ecosystem, including the abundant Archaea and microeukarya. Novel complementation assays need to be developed whereby the metagenomic DNA complements a mutation in a surrogate host. Such methods would be very high throughput since they would allow the positive selection of desired clones. The ability to screen extremely large libraries also makes the use of easier to construct small insert libraries more practical.

While metagenomic approaches offer a means to access the total potential of the microbial gene pool, other approaches need to be considered which may offer new avenues of investigation. One such approach may be to explore the metaproteome of the marine microbes (Fig 1). In metaproteomics the proteins present in an environmental sample are analysed using high throughput methods such as tandem mass spectroscopy [61], comparison of this data to metagenomic DNA sequence data allows one to infer which genes are actively expressed in any population. Using appropriately designed probes this approach would allow the selection of such active genes for the screening and analysis of metagenomic libraries. Using such an approach in tandem perhaps with the more established metagenomic based approaches would greatly enhance the probability of obtaining novel biocatalysts.

\section{Conclusion}

This review is intended to focus the reader's attention on the potential of exploiting metagenomics, specifically the use of metagenomic libraries constructed from unique marine environments as an approach to successfully exploit the largely "untapped" resources within various marine environments. The marine environment is extremely diverse with microbes flourishing in cold polar and warm equatorial waters, in sunlit surface waters, in high-pressure deep sea sediments, in hot acidic water near hydrothermal vents and in association with various vertebrate and invertebrate animals. These diverse ecosystems are potentially very useful sources for novel enzymes with unique properties and great biotechnological potential. Only a small proportion of the bioresources of marine microbiota have thus far been examined and an even smaller proportion has been exploited. Given our present inability to culture the vast majority of microbes from these environments the metagenomic approaches outlined in this review offer the only methodology currently available to access these unique and useful bioresources. There is an ongoing need for a wide range of novel biocat- alysts which are required to improve current and develop new, cleaner, industrial production processes, to reduce energy and raw material consumption, and for the generation of renewable biofuels; marine metagenomics coupled with biotechnology has the potential to contribute to all these pressing needs.

\section{Competing interests}

The authors declare that they have no competing interests.

\section{Authors' contributions}

ADWD drafted the manuscript. JK and JRM contributed additional content throughout the article. All authors have read and approved the final manuscript.

\section{Acknowledgements}

J.K. is in receipt of a Marie Curie Transfer of Knowledge Host Fellowship (Grant No. MTKD-CT-2006-042062). This project was funded by the Marine Biodiscovery Research award funded by the Irish Government under the National Development Plan (2007-2013).

\section{References}

I. Azam F: Oceanography: Microbial Control of Cceanic Carbon Flux: The Plot Thickens. Science 1998, 280:694-696.

2. Azam F, Long RA: Sea snow microcosms. Nature 200I, 4 I 4(6863):495, 497-8.

3. Whitman WB, Coleman DC, Wiebe WJ: Prokaryotes: the unseen majority. Proc Natl Acad Sci U S A 1998, 95( I 2):6578-6583.

4. Amann RI, Ludwig W, Schleifer KH: Phylogenetic identification and in situ detection of individual microbial cells without cultivation. Microbiol Rev 1995, 59(I): 143-169.

5. DeLong EF, Karl DM: Genomic perspectives in microbial oceanography. Nature 2005, 437(7057):336-342.

6. Sogin ML, Morrison HG, Huber JA, Mark Welch D, Huse SM, Neal PR, Arrieta JM, Herndl GJ: Microbial diversity in the deep sea and the underexplored "rare biosphere". Proc Natl Acad Sci U S A 2006, I03(32): $12115-12120$.

7. Venter JC, Remington K, Heidelberg JF, Halpern AL, Rusch D, Eisen JA, Wu D, Paulsen I, Nelson KE, Nelson W, Fouts DE, Levy S, Knap $\mathrm{AH}$, Lomas MW, Nealson K, White O, Peterson J, Hoffman J, Parsons $\mathrm{R}$, Baden-Tillson H, Pfannkoch C, Rogers YH, Smith HO: Environmental genome shotgun sequencing of the Sargasso Sea. Science 2004, 304(5667):66-74.

8. Yooseph S, Sutton G, Rusch DB, Halpern AL, Williamson SJ, Remington K, Eisen JA, Heidelberg KB, Manning G, Li W, Jaroszewski L, Cieplak P, Miller CS, Li H, Mashiyama ST, Joachimiak MP, van Belle C, Chandonia JM, Soergel DA, Zhai Y, Natarajan K, Lee S, Raphael BJ, Bafna V, Friedman R, Brenner SE, Godzik A, Eisenberg D, Dixon JE, Taylor SS, Strausberg RL, Frazier M, Venter JC: The Sorcerer II Global Ocean Sampling expedition: expanding the universe of protein families. PLoS Biol 2007, 5(3):el6.

9. Cowan D, Meyer Q, Stafford W, Muyanga S, Cameron R, Wittwer P: Metagenomic gene discovery: past, present and future. Trends Biotechnol 2005, 23(6):321-329.

10. Handelsman J: Metagenomics: application of genomics to uncultured microorganisms. Microbiol Mol Biol Rev 2004, 68(4):669-685.

II. Stein JL, Marsh TL, Wu KY, Shizuya H, DeLong EF: Characterization of uncultivated prokaryotes: isolation and analysis of a 40-kilobase-pair genome fragment from a planktonic marine archaeon. J Bacteriol 1996, I 78(3):591-599.

12. Lorenz P, Eck J: Metagenomics and industrial applications. Nat Rev Microbiol 2005, 3(6):510-516.

13. Suenaga $H$, Ohnuki T, Miyazaki K: Functional screening of a metagenomic library for genes involved in microbial degradation of aromatic compounds. Environ Microbiol 2007, 9(9):2289-2297.

14. Lammle K, Zipper H, Breuer M, Hauer B, Buta C, Brunner H, Rupp S: Identification of novel enzymes with different hydrolytic 
activities by metagenome expression cloning. J Biotechnol 2007, I 27(4):575-592.

15. Uchiyama T, Abe T, Ikemura T, Watanabe K: Substrate-induced gene-expression screening of environmental metagenome libraries for isolation of catabolic genes. Nat Biotechnol 2005, 23(I):88-93.

16. Seow KT, Meurer G, Gerlitz M, Wendt-Pienkowski E, Hutchinson CR, Davies J: A study of iterative type II polyketide synthases, using bacterial genes cloned from soil DNA: a means to access and use genes from uncultured microorganisms. J Bacteriol 1997, I79(23):7360-7368.

17. Xu M, Xiao X, Wang F: Isolation and characterization of alkane hydroxylases from a metagenomic library of Pacific deep-sea sediment. Extremophiles 2008, I 2(2):255-262.

18. Tang K, Utairungsee T, Kanokratana P, Sriprang R, Champreda V, Eurwilaichitr L, Tanapongpipat S: Characterization of a novel cyclomaltodextrinase expressed from environmental DNA isolated from Bor Khleung hot spring in Thailand. FEMS Microbiol Lett 2006, 260(1):91-99.

19. Hayashi H, Abe T, Sakamoto M, Ohara H, Ikemura T, Sakka K, Benno $Y$ : Direct cloning of genes encoding novel xylanases from the human gut. Can J Microbiol 2005, 5 I (3):25 I-259.

20. Sunna $A$, Bergquist PL: A gene encoding a novel extremely thermostable I,4-beta-xylanase isolated directly from an environmental DNA sample. Extremophiles 2003, 7(1):63-70.

21. Yamada K, Terahara T, Kurata S, Yokomaku T, Tsuneda S, Harayama $S$ : Retrieval of entire genes from environmental DNA by inverse PCR with pre-amplification of target genes using primers containing locked nucleic acids. Environ Microbiol 2008, 10(4):978-987.

22. Boubakri H, Beuf M, Simonet P, Vogel TM: Development of metagenomic DNA shuffling for the construction of a xenobiotic gene. Gene 2006, 375:87-94.

23. Langer M, Gabor EM, Liebeton K, Meurer G, Niehaus F, Schulze R, Eck J, Lorenz P: Metagenomics: an inexhaustible access to nature's diversity. Biotechnol J 2006, I(7-8):8I5-82I.

24. Karl DM: Microbial oceanography: paradigms, processes and promise. Nat Rev Microbiol 2007, 5( I 0):759-769.

25. Kennedy J, Marchesi JR, Dobson AD: Metagenomic approaches to exploit the biotechnological potential of the microbial consortia of marine sponges. Appl Microbiol Biotechnol 2007, 75(I): II-20.

26. Newman DJ, Hill RT: New drugs from marine microbes: the tide is turning. J Ind Microbiol Biotechnol 2006, 33(7):539-544.

27. Sipkema D, Franssen MC, Osinga R, Tramper J, Wijffels RH: Marine sponges as pharmacy. Mar Biotechnol (NY) 2005, 7(3): I 42-162.

28. Ahn YB, Rhee SK, Fennell DE, Kerkhof LJ, Hentschel U, Haggblom MM: Reductive dehalogenation of brominated phenolic compounds by microorganisms associated with the marine sponge Aplysina aerophoba. Appl Environ Microbiol 2003, 69(7):4159-4166.

29. Grozdanov L, Hentschel U: An environmental genomics perspective on the diversity and function of marine sponge-associated microbiota. Curr Opin Microbiol 2007, I O(3):215-220.

30. van Pee KH, Patallo EP: Flavin-dependent halogenases involved in secondary metabolism in bacteria. Appl Microbiol Biotechnol 2006, 70(6):63I-64I.

31. van Pee KH, Unversucht S: Biological dehalogenation and halogenation reactions. Chemosphere 2003, 52(2):299-3I 2.

32. Song $Q$, Zhang $X$ : Characterization of a novel non-specific nuclease from thermophilic bacteriophage GBSVI. BMC Biotechnol 2008, 8:43.

33. de Pascale D, Cusano AM, Autore F, Parrilli E, di Prisco G, Marino G, Tutino ML: The cold-active Lip I lipase from the Antarctic bacterium Pseudoalteromonas haloplanktis TACI 25 is a member of a new bacterial lipolytic enzyme family. Extremophiles 2008, I 2(3):3| I-323.

34. Nishihara M, Kamata M, Koyama T, Yazawa K: New phospholipase Al-producing bacteria from a marine fish. Mar Biotechnol (NY) 2008, I 0(4):382-387.

35. Yoon SA, Ryu SI, Lee SB, Moon TW: Purification and characterization of branching specificity of a novel extracellular amylolytic enzyme from marine hyperthermophilic Rhodothermus marinus. J Microbiol Biotechnol 2008, I 8(3):457-464.
36. $\mathrm{Fu} X \mathrm{X}$, Lin $\mathrm{H}$, Kim SM: Purification and characterization of a novel beta-agarase, AgaA34, from Agarivorans albus YKW34. Appl Microbiol Biotechnol 2008, 78(2):265-273.

37. Itoi S, Kanomata Y, Koyama Y, Kadokura K, Uchida S, Nishio T, Oku $\mathrm{T}$, Sugita $\mathrm{H}$ : Identification of a novel endochitinase from a marine bacterium Vibrio proteolyticus strain No. 442. Biochim Biophys Acta 2007, I774(9): I099-I I07.

38. Kobayashi T, Koide O, Mori K, Shimamura S, Matsuura T, Miura T, Takaki Y, Morono Y, Nunoura T, Imachi H, Inagaki F, Takai K, Horikoshi K: Phylogenetic and enzymatic diversity of deep subseafloor aerobic microorganisms in organics- and methane-rich sediments off Shimokita Peninsula. Extremophiles 2008, I 2(4):5 | 9-527.

39. Yokouchi H, Fukuoka Y, Mukoyama D, Calugay R, Takeyama H, Matsunaga $\mathrm{T}$ : Whole-metagenome amplification of a microbial community associated with scleractinian coral by multiple displacement amplification using phi29 polymerase. Environ Microbiol 2006, 8(7): I I55-I I63.

40. Gabor EM, Alkema WB, Janssen DB: Quantifying the accessibility of the metagenome by random expression cloning techniques. Environ Microbiol 2004, 6(9):879-886.

4I. Smith HE: The transcriptional response of Escherichia coli to recombinant protein insolubility. I Struct Funct Genomics 2007, 8(I):27-35.

42. Martinez A, Kolvek SJ, Yip CL, Hopke J, Brown KA, MacNeil IA, Osburne MS: Genetically modified bacterial strains and novel bacterial artificial chromosome shuttle vectors for constructing environmental libraries and detecting heterologous natural products in multiple expression hosts. Appl Environ Microbiol 2004, 70(4):2452-2463.

43. Wexler M, Bond PL, Richardson DJ, Johnston AW: A wide hostrange metagenomic library from a waste water treatment plant yields a novel alcohol/aldehyde dehydrogenase. Environ Microbiol 2005, 7(1 2): 1917-1926.

44. Niiranen L, Espelid S, Karlsen CR, Mustonen M, Paulsen SM, Heikinheimo P, Willassen NP: Comparative expression study to increase the solubility of cold adapted Vibrio proteins in Escherichia coli. Protein Expr Purif 2007, 52(1):210-218.

45. Ferrer M, Chernikova TN, Yakimov MM, Golyshin PN, Timmis KN: Chaperonins govern growth of Escherichia coli at low temperatures. Nat Biotechnol 2003, 2 I (I I):I266-1267.

46. Ferrer M, Chernikova TN, Timmis KN, Golyshin PN: Expression of a temperature-sensitive esterase in a novel chaperone-based Escherichia coli strain. Appl Environ Microbiol 2004, 70(8):4499-4504.

47. Brady SF, Chao CJ, Handelsman J, Clardy J: Cloning and heterologous expression of a natural product biosynthetic gene cluster from eDNA. Org Lett 200I, 3(13): I98I-1984.

48. Brady SF, Chao CJ, Clardy J: New natural product families from an environmental DNA (eDNA) gene cluster. J Am Chem Soc 2002, I 24(34):9968-9969.

49. Gillespie DE, Brady SF, Bettermann AD, Cianciotto NP, Liles MR, Rondon MR, Clardy J, Goodman RM, Handelsman J: Isolation of antibiotics turbomycin a and $B$ from a metagenomic library of soil microbial DNA. Appl Environ Microbiol 2002, 68(9):430I-4306.

50. MacNeil IA, Tiong CL, Minor C, August PR, Grossman TH, Loiacono KA, Lynch BA, Phillips T, Narula S, Sundaramoorthi R, Tyler A, Aldredge T, Long H, Gilman M, Holt D, Osburne MS: Expression and isolation of antimicrobial small molecules from soil DNA libraries. I Mol Microbiol Biotechnol 200I, 3(2):30I-308.

5I. Wang GY, Graziani E, Waters B, Pan W, Li X, McDermott J, Meurer G, Saxena G, Andersen RJ, Davies J: Novel natural products from soil DNA libraries in a streptomycete host. Org Lett 2000, 2(16):240I-2404

52. Long PF, Dunlap WC, Battershill CN, Jaspars M: Shotgun cloning and heterologous expression of the patellamide gene cluster as a strategy to achieving sustained metabolite production. Chembiochem 2005, 6(10): 1760-1765.

53. Schmidt EW, Nelson JT, Rasko DA, Sudek S, Eisen JA, Haygood MG, Ravel J: Patellamide $\mathbf{A}$ and $\mathbf{C}$ biosynthesis by a microcin-like pathway in Prochloron didemni, the cyanobacterial symbiont of Lissoclinum patella. Proc Natl Acad Sci U S A 2005, 102(20):73I5-7320.

54. Acevedo JP, Reyes F, Parra LP, Salazar O, Andrews BA, Asenjo JA: Cloning of complete genes for novel hydrolytic enzymes 
from Antarctic sea water bacteria by use of an improved genome walking technique. J Biotechnol 2008, I33(3):277-286.

55. Hardeman F, Sjoling S: Metagenomic approach for the isolation of a novel low-temperature-active lipase from uncultured bacteria of marine sediment. FEMS Microbiol Ecol 2007, 59(2):524-534.

56. Jaeger KE, Dijkstra BW, Reetz MT: Bacterial biocatalysts: molecular biology, three-dimensional structures, and biotechnological applications of lipases. Annu Rev Microbiol 1999, 53:3|5-35I.

57. Jaeger KE, Eggert T: Lipases for biotechnology. Curr Opin Biotechnol 2002, I3(4):390-397.

58. Podar M, Abulencia CB, Walcher M, Hutchison D, Zengler K, Garcia JA, Holland T, Cotton D, Hauser L, Keller M: Targeted access to the genomes of low-abundance organisms in complex microbial communities. Appl Environ Microbiol 2007, 73(I0):3205-32I 4.

59. Marcy Y, Ouverney C, Bik EM, Losekann T, Ivanova N, Martin HG, Szeto E, Platt D, Hugenholtz P, Relman DA, Quake SR: Dissecting biological "dark matter" with single-cell genetic analysis of rare and uncultivated TM7 microbes from the human mouth. Proc Natl Acad Sci U S A 2007, 104(29): I I889-I I 894.

60. Stepanauskas R, Sieracki ME: Matching phylogeny and metabolism in the uncultured marine bacteria, one cell at a time. Proc Natl Acad Sci U S A 2007, 104(2 I):9052-9057.

6I. Banfield JF, Verberkmoes NC, Hettich RL, Thelen MP: Proteogenomic approaches for the molecular characterization of natural microbial communities. Omics 2005, 9(4):30I-333.

62. Irwin JA, Lynch SV, Coughlan S, Baker PJ, Gudmundsson HM, Alfredsson GA, Rice DW, Engel PC: Alanine dehydrogenase from the psychrophilic bacterium strain PA-43: overexpression, molecular characterization, and sequence analysis. Extremophiles 2003, 7(2): 135- 143.

63. Kazuoka T, Oikawa T, Muraoka I, Kuroda S, Soda K: A cold-active and thermostable alcohol dehydrogenase of a psychrotorelant from Antarctic seawater, Flavobacterium frigidimaris KUC-I. Extremophiles 2007, I I (2):257-267.

64. Huston AL, Methe B, Deming JW: Purification, characterization, and sequencing of an extracellular cold-active aminopeptidase produced by marine psychrophile Colwellia psychrerythraea strain $34 \mathrm{H}$. Appl Environ Microbiol 2004, 70(6):3321-3328.

65. Zhang JW, Zeng RY: Purification and characterization of a coldadapted alpha-amylase produced by Nocardiopsis sp. 7326 isolated from Prydz Bay, Antarctic. Mar Biotechnol (NY) 2008, I O(I):75-82.

66. Coker JA, Brenchley JE: Protein engineering of a cold-active beta-galactosidase from Arthrobacter sp. SB to increase lactose hydrolysis reveals new sites affecting low temperature activity. Extremophiles 2006, 10(6):515-524.

67. Nakagawa T, Ikehata R, Uchino M, Miyaji T, Takano K, Tomizuka N: Cold-active acid beta-galactosidase activity of isolated psychrophilic-basidiomycetous yeast Guehomyces pullulans. Microbiol Res 2006, I6I ( I):75-79.

68. Lorentzen MS, Moe E, Jouve HM, Willassen NP: Cold-adapted features of Vibrio salmonicida catalase: characterisation and comparison with the mesophilic counterpart from Proteus mirabilis. Extremophiles 2006.

69. Garsoux G, Lamotte J, Gerday C, Feller G: Kinetic and structural optimization to catalysis at low temperatures in a psychrophilic cellulase from the Antarctic bacterium Pseudoalteromonas haloplanktis. Biochem J 2004, 384(Pt 2):247-253.

70. Zeng $\mathrm{R}$, Xiong $\mathrm{P}, \mathrm{Wen} \mathrm{J}$ : Characterization and gene cloning of a cold-active cellulase from a deep-sea psychrotrophic bacterium Pseudoalteromonas sp. DY3. Extremophiles 2006, IO(I):79-82

7I. Lonhienne T, Baise E, Feller G, Bouriotis V, Gerday C: Enzyme activity determination on macromolecular substrates by isothermal titration calorimetry: application to mesophilic and psychrophilic chitinases. Biochim Biophys Acta 200I, I 545(I2):349-356.

72. Hobel CF, Hreggvidsson GO, Marteinsson VT, Bahrani-Mougeot F, Einarsson JM, Kristjansson JK: Cloning, expression, and characterization of a highly thermostable family 18 chitinase from Rhodothermus marinus. Extremophiles 2005, 9(I):53-64.
73. Park SY, Kim JT, Kang SG, Woo JH, Lee JH, Choi HT, Kim SJ: A new esterase showing similarity to putative dienelactone hydrolase from a strict marine bacterium, Vibrio sp. GMD509. Appl Microbiol Biotechnol 2007, 77(I): I07-I I5.

74. Woo JH, Hwang YO, Kang SG, Lee HS, Cho JC, Kim SJ: Cloning and characterization of three epoxide hydrolases from a marine bacterium, Erythrobacter litoralis HTCC2594. Appl Microbiol Biotechnol 2007, 76(2):365-375

75. Aurilia V, Parracino A, D'Auria S: Microbial carbohydrate esterases in cold adapted environments. Gene 2008, 410(2):234-240.

76. Cristobal HA, Breccia JD, Abate CM: Isolation and molecular characterization of Shewanella sp. G5, a producer of coldactive beta-D-glucosidases. J Basic Microbiol 2008, 48(I): 16-24.

77. Goudarzi M, Born TL: Purification and characterization of Thermotoga maritima homoserine transsuccinylase indicates it is a transacetylase. Extremophiles 2006, I0(5):469-478.

78. Maki S, Yoneta M, Takada Y: Two isocitrate dehydrogenases from a psychrophilic bacterium, Colwellia psychrerythraea. Extremophiles 2006, I0(3):237-249.

79. Sato Y, Watanabe S, Yamaoka N, Takada Y: Gene cloning of coldadapted isocitrate lyase from a psychrophilic bacterium, Colwellia psychrerythraea, and analysis of amino acid residues involved in cold adaptation of this enzyme. Extremophiles 2008, I2(I): 107-II7.

80. Oikawa T, Yamamoto N, Shimoke K, Uesato S, Ikeuchi T, Fujioka T: Purification, characterization, and overexpression of psychrophilic and thermolabile malate dehydrogenase of a novel antarctic psychrotolerant, Flavobacterium frigidimaris KUC-I. Biosci Biotechnol Biochem 2005, 69(II):2I 46-2I54.

8I. Qureshi MH, Kato C, Horikoshi K: Purification of a ccb-type quinol oxidase specifically induced in a deep-sea barophilic bacterium, Shewanella sp. strain DB-172F. Extremophiles 1998, 2(2):93-99.

82. Truong LV, Tuyen H, Helmke E, Binh LT, Schweder T: Cloning of two pectate lyase genes from the marine Antarctic bacterium Pseudoalteromonas haloplanktis strain ANT/505 and characterization of the enzymes. Extremophiles 200I, 5(I):35-44.

83. Olivera NL, Sequeiros C, Nievas ML: Diversity and enzyme properties of protease-producing bacteria isolated from sub-Antarctic sediments of Isla de Los Estados, Argentina. Extremophiles 2007, I I(3):517-526.

84. Zeng R, Zhang R, Zhao J, Lin N: Cold-active serine alkaline protease from the psychrophilic bacterium Pseudomonas strain DY-A: enzyme purification and characterization. Extremophiles 2003, 7(4):335-337.

85. Chavez Croocker P, Sako Y, Uchida A: Purification and characterization of an intracellular heat-stable proteinase (pernilase) from the marine hyperthermophilic archaeon Aeropyrum pernix KI. Extremophiles 1999, 3(I):3-9.

86. Davail S, Feller G, Narinx E, Gerday C: Cold adaptation of proteins. Purification, characterization, and sequence of the heat-labile subtilisin from the antarctic psychrophile Bacillus TA4I. J Biol Chem 1994, 269(26): I7448-17453.

87. Jorge CD, Sampaio MM, Hreggvidsson GO, Kristjanson JK, Santos H A highly thermostable trehalase from the thermophilic bacterium Rhodothermus marinus. Extremophiles 2007, I I(I): I I5-I 22.

88. Jaeger S, Schmuck R, Sobek H: Molecular cloning, sequency, and expression of the heat-labile uracil-DNA glycosylase from a marine psychrophilic bacterium, strain BMTU3346. Extremophiles 2000, 4(2): II 15-I 22.

89. Collins T, Meuwis MA, Stals I, Claeyssens M, Feller G, Gerday C: A novel family 8 xylanase, functional and physicochemical characterization. J Biol Chem 2002, 277(38):35133-35I39. 